\title{
Pemanfaatan Media Sosial Sebagai Media E-Marketing Untuk Pemasaran UMKN Karang Taruna Desa Kota Batu
}

\author{
Hilda Amalia ${ }^{1}$, Ida Darwati ${ }^{2}$, Nuzuliarini Nuris ${ }^{3}$, Dinda Ayu Muthia ${ }^{4}$ \\ 1,2,3,4 Universitas Bina Sarana Informatika \\ Jl. Kramat Raya No 98 Jakarta Pusat, Indonesia \\ e-mail: ${ }^{1}$ hilda.ham@bsi.ac.id, ${ }^{2}$ ida.idd@bsi.ac.id, ${ }^{3}$ nuzuliarini.nzn@bsi.ac.id, \\ 4dinda.dam@bsi.ac.id
}

\begin{abstract}
Abstrak
Perkembangan penggunaan media sosial merupakan suatu peluang yang harus dimanfaatkan dengan baik sehingga dapat dimanfaatkan sebagai salah satu teknik e-marketing yang mampu meningkatkan pemasaran produk. Dalam era digital dan pandemic covid 19 menuntut setiap orang untuk mampu melakukan aktivitas dari rumah. Untuk itu teknik e-martketing merupakan salah satu teknik pemasaran yang menjadi kunci sukses dari kegiatan pemasaran suatu produk. Sosial media merupakan suatu aplikasi yang banyak digunakan oleh banyak orang dan diakses setiap saat. Media sosial menjadi salah satu cara yang paling cepat dalam menyebarkan informasi. Masyarakat dapat dengan mudah medapatkan media informasi. Karang Taruna Desa Kota Batu merupakan suatu wadah kepemudaan pada kantor desa Kota Batu. Karang taruna memiliki UMKM yaitu produk masker N95. Karang Taruna Desa Kota Batu menangkap peluang yang ada dari masa pendemic dengan menjaul maskter. Namun Karang Taruna Desa Kota Batu memiliki kesulitan dalam melakukan pemasaran produk. Untuk itu diperlukan suatu pelatihan pengelolaan Media Sosial untuk bisa digunakan sebagai elektronik marketing (e-marketing). Sehingga Karang Taruna Desa Kota Batu mampu memanfaatkan media sosial dengan baik dan pada akhirnya mampu memperluas lingkup pemasaran serta mampu meningkatkan penjualan produk.
\end{abstract}

Kata Kunci: Media Sosial, E-Marketing

Abstract

The development of the use of social media is an opportunity that must be utilized properly so that it can be used as an e-marketing technique that can improve product marketing. In the digital era and the Covid 19 pandemic, everyone is required to be able to carry out activities from home. For this reason, the e-marketing technique is one of the marketing techniques that is the key to the success of marketing a product. Social media is an application that is widely used by many people and accessed at any time. Social media is one of the fastest ways to spread information. The public can easily get media information. Karang Taruna Village of Kota Batu is a youth forum at the Kota Batu village office. Youth organizations have UMKN, namely $N 95$ mask products. Karang Taruna Village of Kota Batu seized the opportunities that existed from the pandemic period by selling masks. However, Karang Taruna Desa Kota Batu has difficulties in marketing the product. For that we need training on social media management to be used as electronic marketing (e-marketing). So that Karang Taruna Village Kota Batu is able to make good use of social media and in the end is able to expand the scope of marketing and be able to increase product sales.

Keyswords: Social Media, E-Marketing, Marketing 


\section{Pendahuluan}

Mitra pada pengabdian masyarakat semester genap 2020/2021 yaitu Karang Taruna Kota Batu yang berlokasi di Desa Kota Batu, Kecamatan Ciomas, Kabupaten Bogor. Berdasarkan informasi yang diperoleh dari Karang Taruna Kota Batu, Karang Taruna Kota Batu terbentuk kembali tanggal 4 Januari 2020 memiliki tekad untuk memajukan Desa Kota Batu dengan peran aktif dari para pemuda dan pemudi. Saat ini karang taruna mencoba usaha yang sedang dirintis Karang Taruna Kota Batu yaitu berjualan masker KN95. Kegiatan karang taruna ini merupakan kegiatan positif yang harus diapresiasi. Dimasa pandemi seperti sekarang ini, berjualan secara online lebih diutamakan dan memiliki peran yang sangat penting dalam promosi serta meningkatkan penjualan karena pemasarannya dapat mencakup luar Kabupaten Bogor. Namun hal ini tidaklah mudah karena karang taruna memiliki permasalahan yang dialami oleh karang taruna adalah kurangnya kemampuan dan pengetahuan dalam mengelola sosial media atau digital marketing sehingga dapat meningkatan pemasaran produk yaitu masket KN95. Saat ini perkembangan teknologi informasi berkembang sangat pesat menutut setiap orang untuk mampu menguasai teknologi-teknologi tersebut. Terlebih lagi di kondisi pandemic saat ini yang membuat segala kegiatan berjalan menggunakan teknologi. Mitra kami yakni karang taruna kota batu mengalami kesulitan untuk beradaptasi dengan penggunaaan teknologi untuk pemanfaatan nya sebagai sarana promosi produk. Salah satu teknologi yang menjadi sarana melakukan promosi yang efektif adalah media sosial. Media sosial seharusnya dima (Mahendy, 2016)nfaatkan sebagai salah satu komponen penting dalam strategi pemasaran pada setiap bisnis dengan skala kecil sampai korporat(Widiayaningrum, 2016).

Media sosial adalah suatu teknologi yang memungkinan orang berinterkansi tanpa terhalang ruang dan waktu(Pribadi dkk, 2018). Media sosial merupakan salah satu dari teknik emarketing atau digital marketing. Pemanfaatan media sosial menjadi hal yang penting digunakan untuk mempromosikan suatu produk dan menyebarkan produk menjadi lebih cepat. Dengan keunggulan media sosial membuat sosial media menjadi salahsatu digital marketing yang dapat diandalkan untuk melakukan promosi. sosial media marketing sebagai media yang murah dan efektif dalam memasarkan produk/jasa secara online. Promosi yang dilakukan di media sosial dapat mengenalkan produk ke banyak orang (Sukri \& Arisandi, 2017)

Namun kondisi mitra saat ini belum mampu memnguasai dan memahami bagaiamna sosial media dapat meningkatkan promosi produk mereka dan pada akhirnya meningkatkan penjualan. Untuk itu diharapkan dengan adanya kegaitan PKM ini pada karang taruna desa kota batu diharapkan dapat meningkatkan pengetahun dan keterampilan mitra tentag emarketing penggunaan sosial media sebagai sarana publikasi produk. Melalui pelatihanpelatihan pengelolaan sosial media diketahui sangat bermanfaat sebagai sarana pemasaran(Mahendy, 2016)

\section{Metode}

Metode Pelaksanaan Pengabdian

PKM dilaksanaan oleh tim pelaksan yang terdiri dari empat orang dosen dan dua mahasiswa Universitas Bina Sarana Informatika Program Studi Sistem Informasi. Kegiatan dilaksanakan 


\section{ABDITEKNIKA}

Jurnal Pengabdian Kepada Masyarakat

Volume 1 Nomor 2 Oktober 2021

ISSN 2775-1694

di Kantor Desa Kota Batu dengan yang dihadiri oleh peserta yaitu Karang Taruna Desa Kota Batu. Karang Taruna Desa Kota Batu mengalami kesulitan dalam melakukan pemasaran produk yaitu Masker 95. Metode pelaksanaan yang dilakukan adalah dengan memberika pelatihan pengelolaan media sosial dengan menggunakan aplikasi CANVAS. Media sosialyang digunakan disini adalah Instagram. CANVAS merupakan aplikasi mobile yang dapat dimanfaatkan untuk meningkatkan tampilan instagram.
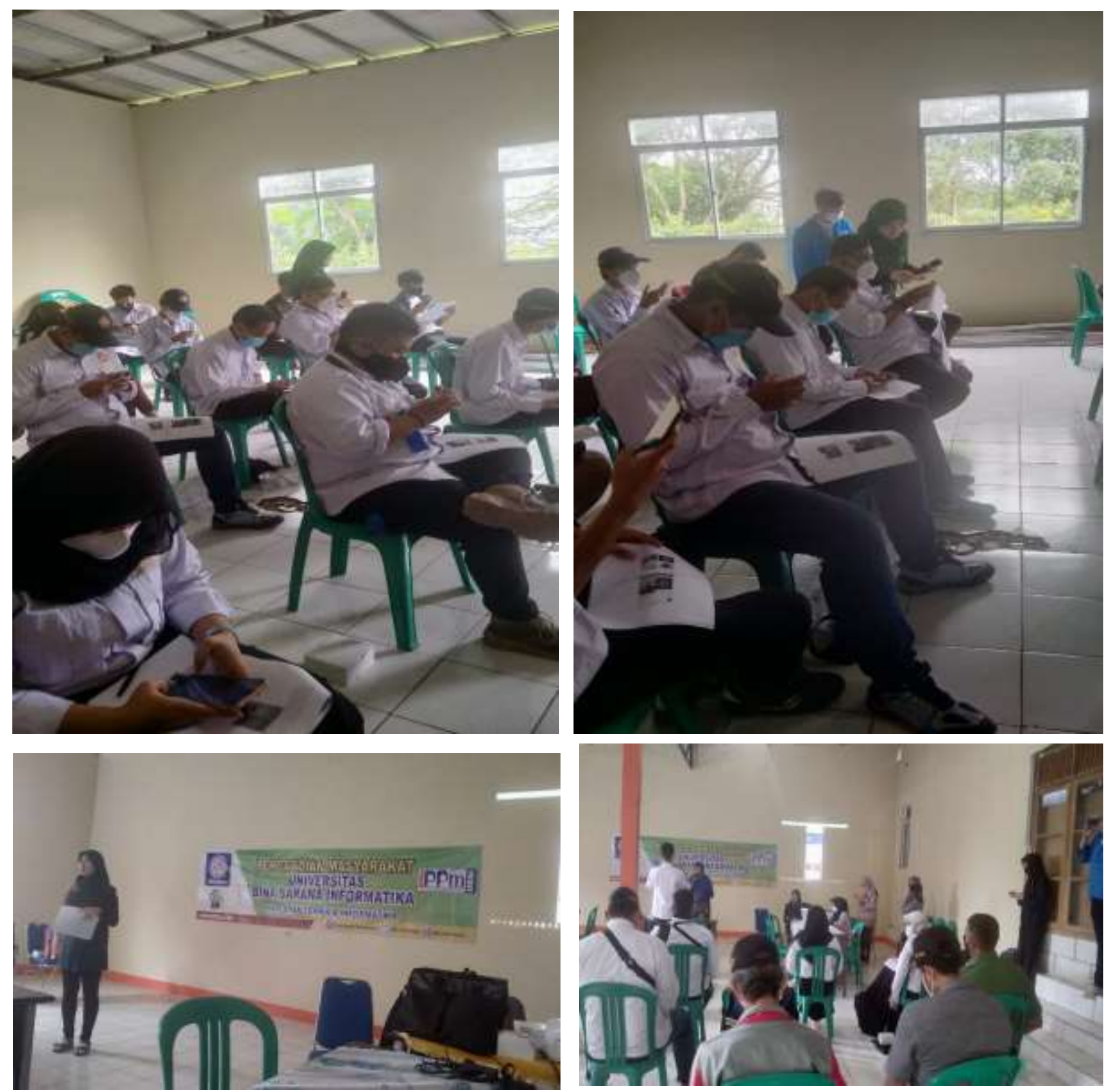

Gambar 1. Pelaksanaan Kegiatan Pelatihan Pengabdian Masyarakat

\section{Hasil dan Pembahasan}

Untuk meningkatkan kemampuan masyarakat mengenai pemanfaatan media sosial sebagai sarana pemasaran secara elektronik atau e-marketing yaitu dilakukan pelatihan membuat 


\section{ABDITEKNIKA}

Jurnal Pengabdian Kepada Masyarakat

tampilan produk yang menarik untuk di post pada halaman sosial media yaitu Instagram. Hasil yang diperoleh mitra dari kegiatan pelatihan ini yaitu adanya peningkatan pengetahuan mengenai pemanfaatan pemasaran secara elektronik dengan memanfaatkan sosial media yang dimiliki.

Medis sosial yang digunakan adalah instagram dan aplikasi yang digunakan untuk membuat tampilan foto menjadi lebih menarik sehingga mampu membuat customer tertarik untuk melihat. Dari kegiatan pengabdian pengabdian masyarakat ini mendapatkan manfaat bagi peserta yaitu dalam bentuk peningkatan pengetahuan mengenai mengelola foto produk untuk dipublish di media sosial dengan menggunakan software CANVAS sehingga akan lebih menarik para netizen yang pada akhirnya meningkatkan pemasaran produk. Peningkatan pengetahuan peserta disajikan dalam bentuk grafik penigkatan pengetahuan.

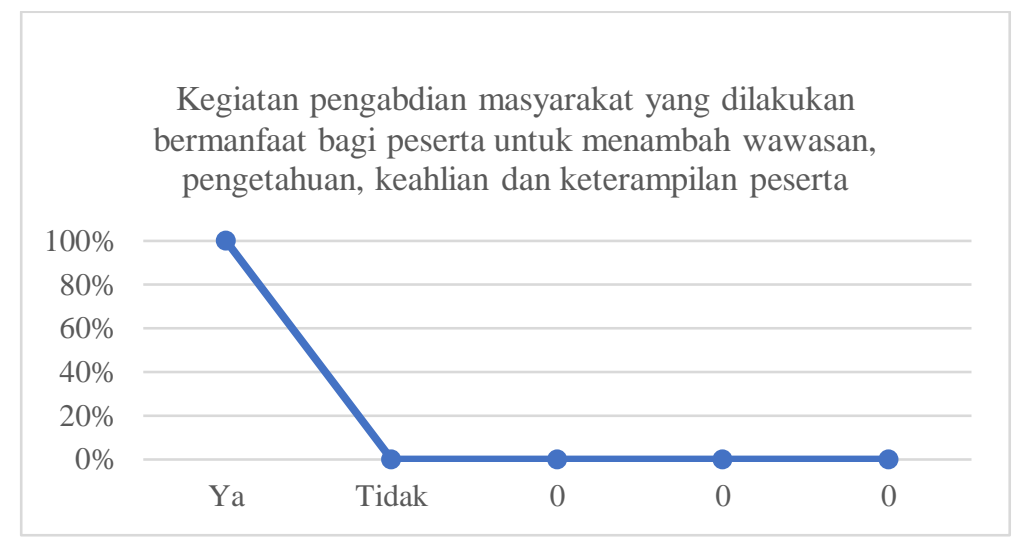

\section{Gambar 2. Kegiatan pengabdian masyarakat yang dilakukan bermanfaat bagi peserta untuk menambah wawasan, pengetahuan, keahlian dan keterampilan peserta}

Dari grafik gambar 2 diketahui bahwa dengan adanya kegiatan pengabdian masyarakat bermanfaat dan mampu menambah wawasan, pengetahuan dan keterampilan peserta dalam hal ini menggunakan aplikasi CANVAS untuk melakukan design foto produk untuk di tampilkan dalam Sosial Media sebagai media pemasaran produk

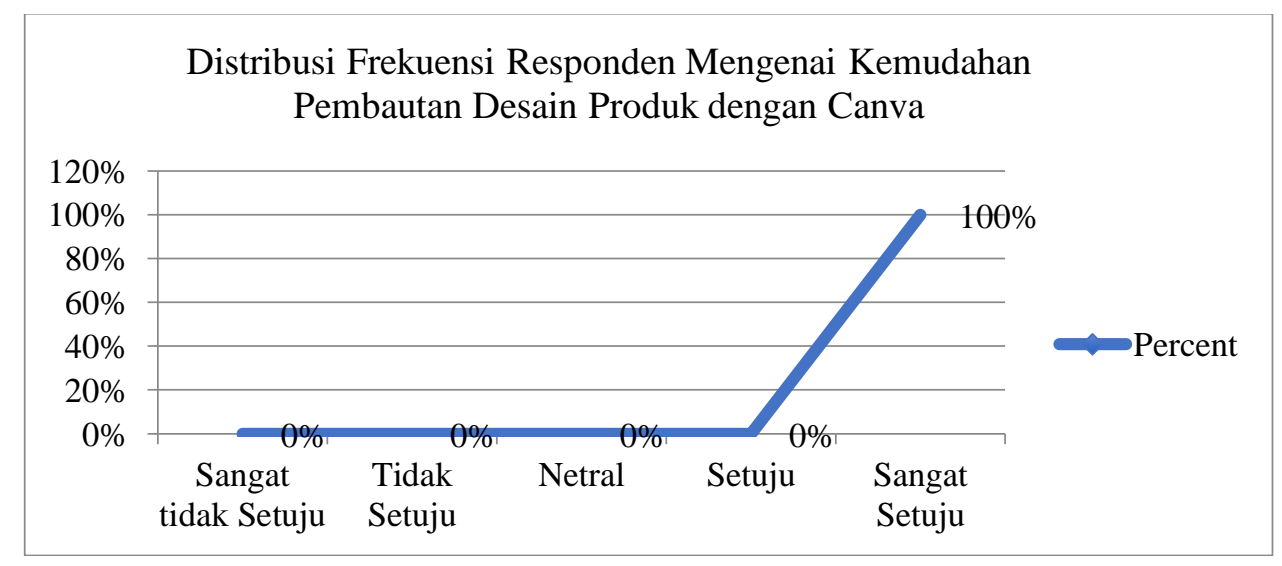

Gambar 3 Grafik Responden mengenai Kemudahan Pembuatan Desain Produk Dengan Aplikasi CANVA 
Pada gambar 3 disajikan bahwa mitra atau peserta pelatihan memberikan tanggapan mengenai kemudahan penggunaan atau pemanfaatan canva dalam pembuatan desain produk untuk kemudia di sebar luaskan melalui media sosial.

\section{Kesimpulan}

Berdasarkan kegiatan yang telah dilakukan dapat disimpulkan bahwa peserta yaitu karang taruna kota batu belum mampu melakukan pengelolaan foto yang menarik untuk pemasaran produk masker KN95 atau belum mampu memanfaatkan media sosial dalam hal ini instagram untuk meningkatkan pemsaran produk UMKN Karang Taruna Desa Kota Batu. Setelah dilakukan kegiatan pengabdian masyarakat ini maka terjadi peningkatan pengetahuan sehingga peserta mampu melakukan pengolahan atau pengeditan foto produk menjadi lebih menarik. Sebelum pelaksanan pelatihan ini masyarakat atau mitra hanya menggunakan pemasaran dari mulut ke mulut dengan adanya pelatihan ini mitra mampu membuat tampilan promosi produk menjadi lebih menarik dan di sebar luaskan melalui media sosial yaitu Instagram. Dengan adanya peningkatakn keahlian dan pengetahuan Karang Taruna Desa Kota Batu diharapakan mampu menigkatan kegiatan pemasarand dan penjualan produk

\section{Daftar Pustaka}

Mahendy, K. S. (2016). Pelatihan Pemanfaatan Media Online Sebagai Sarana Pemasaran Hasil Produksi Bagi Asosiasi Pengrajin industri Kecil (APIK)Kabupaten Buleleng. Seminar Nasional Pengabdian Kepada Masyarakat, 238-298.

Pribadi, A., Ghozali, K., Hidayanto, B. C., Hadifz, I., Muqtadiroh, F. A., Hafidz, M. A., et al. (2018). Pelatihan Teknik Sosial Media Marketing sebagai Sarana Pemasaran Produk Konveksi Kerudung 'AL Kattar' Di Kelurahan Merjosari, Malang. Jurnal Pengabdian kepada Masyarakat SEWAGATI, 2(1), 53-59.

Ridwan, I. M., Fauzi, A., Aisyah, I., Susilawati, \& Sofyan, I. (2019). Penerapan Digital Marketing Sebagai Peningkatan Pemasaran Pada UKM Warung Angkringan "WAGE" Bandung. Jurnal Abdimas BSI, 2(1), 137-148.

Sukri, \& Arisandi, D. (2017). Analisis Strategi Pemasaran Dengan Media Sosial Produk KulinerUsaha Kecil dan Menengah di Pekanbaru. Jurnal Buana Informatika, 235-242.

Widyaningrum, P. W. (2016). Peran Media Sosial sebagai Strategi Pemasaran pada Sewa Kostum Meiyu Aiko Malang. Al Tijarah, 230-277. 